УДК 657.1.011.56

DOI: https://doi.org/10.26642/jen-2019-4(90)-167-175

Л.Ф. Соколенко, к.е.н., доц.

Сумський державний педагогічний університет імені А.С. Макаренка

\title{
Розвиток процесів цифровізації як передумова трансформації організаційно-методологічних засад бухгалтерського обліку
}

\begin{abstract}
Цифровізачія суспільства є логічним етапом його розвитку, який в сфері економічних взаємовідносин виявляється у конщепиії Індустрї 4.0. Цифровізація бізнес-процесів пронизує всі існуючі комунікаційні відносини між суб'єктами трансакцій та стейкхолдерами. Вона створює для них нове віртуальне середовище, пропонуючи нові форми інформаційних взаємин між ними. Флагманами переходу до ичиррового суспільства стають компанії, які активно впроваджують цифрові технології у бізнес-процеси. Виклики, яке ставить глобалізоване економічне середовище до стратегій сучасних компаній, обумовлюють потребу їх долучення до прочесів циифровізаціі суспільства, шуо виявляється у зміні парадигми взаємодії економічних агентів. Це трансформує організаційно-методологічні засади системи бухгалтерського обліку як інформаційної системи компаніі.

Метою статті є дослідження особливостей перебігу процесів ицифровізації суспільства в контексті стану соціально-економічного розвитку краӥн та регіонів для з'ясування рис трансформації системи комунікації між економічними агентами як користувачами облікової інформаиії.

Встановлено, щчо ичифровізація як середовище перебігу економічних процесів та здійснення трансакцій викликає модифікацію методичного інструментарію бухгалтерського обліку, віртуалізує прочеси організації бухгалтерського обліку. 3 одного боку, ие означає зниження ризиків викривлення інформації, інтегруючи модулі взаємодії облікового персоналу та економічних агентів. 3 другого - формує нові ризики та загрози функціонування системи бухгалтерського обліку.
\end{abstract}

Ключові слова: цүифровізація; бухгалтерський облік; сфера послуг; хмарні сервіси; організація бухгалтерського обліку.

Актуальність теми. Цифровізація $є$ передумовою глобальних суспільних перетворень, що визначають траєкторію розвитку сучасного бізнесу, забезпечує безпрецедентні можливості створення вартості на основі його віртуалізації. Вона $є$ логічним етапом розвитку суспільства, який у сфері економічних взаємовідносин виявляється у концепції Індустрії 4.0. Все частіше у стратегічних планах країн згадується про необхідність побудови цифрового суспільства, розвитку цифрової економіки, ознаками якої і є віртуалізація всіх суспільно-економічних, освітніх, соціальних та політичних процесів.

Виклики, яке ставить глобалізоване економічне середовище до стратегій сучасних компаній, обумовлюють потребу їх долучення до процесів цифровізації суспільства, що виявляється у зміні парадигми взаємодії економічних агентів. I флагманами переходу до цифрового економічного простору стають компанії, які активно впроваджують цифрові технології у бізнес-процеси. Цифровізація бізнеспроцесів пронизує всі існуючі комунікаційні відносини між суб'єктами трансакцій та стейкхолдерами. Вона створює для них нове віртуальне середовище, пропонуючи нові форми інформаційних взаємин між ними. Це трансформує і організаційно-методологічні засади системи бухгалтерського обліку як інформаційної системи компанії, що визначає актуальність цього дослідження.

Аналіз останніх досліджень та публікації, на які спирається автор. Для дослідження вказаних питань нами вивчено підходи зарубіжних вчених і дослідників з питань суспільного сприйняття та значення електронних сервісів для розвитку громадянського суспільства й поліпшення соціальноекономічних умов життя населення. Так дані питання досліджували у своїх працях Х.Маргеттс (H.Margetts), П.Данліві (P.Dunleavy) [14], М.Густафсон (M.Gustafsson), В.Елін (W.Elin) [9], Р.Буййа (R.Buyуa), Р.Ранджан (R.Ranjan), P.Н. Кал’єрос (R.N. Calheiros) [3], Дж.Голдкул (G.Goldkuhl), А.Перссон (A.Persson) [8], Д. Беланже (D.Belanche) [2], К.Аксельсон (K.Axelsson), У.Мелін (U.Melin) [1], Дж.Хайдеманн (J.Heidemann), С.Маштер (S.Muschter), K.Pox (C.Rauch) [10], M.C. Фітерман (M.S. Featherman.), П.А. Павлоу (P.A. Pavlou) [7], І.Ліндгрен (I. Lindgren), Дж.Дженсон (G.Jansson) [13], Л.Ільшаммар (L.Ilshammar), А.Бйорстрьом (A.Bjurström), А.Грьонлунд (Å.Grönlund.) [11], Н.Казаліно (N.Casalino.), М.Драолі (M.Draoli), M.Мартіно (M.Martino) [4] та інші. Їх науковий доробок складає базис формування уявлення про передумови трансформації організаційно-методологічних засад системи бухгалтерського обліку, оскільки долученість економічних агентів до використання хмарних сервісів та створення віртуальної взаємодії трансформує можливості передачі, обробки та використання даних, що створені у системі бухгалтерського обліку. 
Метою статті є дослідження особливостей перебігу процесів цифровізації суспільства в контексті стану соціально-економічного розвитку країн та регіонів для з'ясування рис трансформації системи комунікації між економічними агентами як користувачами облікової інформації.

Викладення основного матеріалу. Поняття «цифровізації» $є$ новим як для практиків, так i для теоретиків економічної науки, зокрема науки бухгалтерського обліку. У зв'язку з цим спостерігається підміна понять, які часто помилково вважають синонімічними - «інформатизація» та «цифровізація». I якщо перше з них є давно поширеним і у теорії, і у практиці бухгалтерського обліку, то друге введено в науковий обіг відносно нещодавно.

Зокрема, інформатизація не модифікує принципи взаємодії між економічними агентами, а лише створює додаткові канали поширення даних, дублюючи (а іноді і просто відтворюючи) іiі аналогову форму у цифровому вигляді. Крім того, зміна формату генерування та передачі даних в інформатизованій системі бухгалтерського обліку створює лише ряд інших, відмінних від паперових, засобів інформаційної взаємодії економічних агентів. Проте цифровізація системи бухгалтерського обліку визначає нову концепцію формування та використання даних, дозволяє цифровізувати та параметризувати ряд об'єктів, які класично не є об'єктами бухгалтерського обліку. А тому якісно нові бази даних щодо бізнес-процесів компанії сприяють утворенню прогностичних функцій системи бухгалтерського обліку, що можуть бути використані всіма підсистемами управління компанії.

За словами Ю.І. Онищенко, «всі дослідження у сфері "цифрової економіки" умовно поділити на три основні періоди: перший (1995-2001рр.), на якому відбувалося становлення наукової думки щодо сутності поняття «цифрова економіка» та формувалися базові інновації; другий (2010-2016 рр.), на якому ця категорія затверджується на законодавчому рівні; третій (3 2016 р.), на якому проводяться фундаментальні теоретичні дослідження щодо сутності поняття «цифрова економіка» [21, с. 12]. 3 цього приводу слід загадати досвід нових індустріальних країн Гонконгу, Сінгапуру, Тайваню тощо. В цьому випадку цифровізація охопила як виробничі процеси, так і сферу послуг, особливо фінансовий сектор та сектор інформації і телекомунікацій.

Зростання обсягів даних, динамізація і трансформація їх оброки, потреби забезпечення кібербезпеки прискорює та посилює вплив цифрових технологій, що вимагає змін бізнес-моделей існуючих підприємств. Вони стають змушені докорінно переглядати бізнес-процеси, які, охоплюючи можливості цифровізації, розширюють потенціал співпраці з партнерами та обслуговування клієнтів.

Констатуємо також, що фірми як агенти створення доданої вартості змушені модернізувати свою структуру, удосконалювати професійні навички працівників та змінювати практику найму. Всі сервіси та бізнес-процеси фірми починають базуватися на «Великих даних» (BigData), a їх використання та можливості обробки дають стратегічні переваги у виробництві, маркетингу, управлінні ресурсами кастомізації товарів та послуг, таргетування реклами та клієнтських сервісів.

У цих умовах цифрові сервіси та цифрове середовище із інструментів бізнесу стають повноцінним продуктом. Зростання провідних інформаційних платформ обумовлено зростанням даних, що генеруються у світі. При цьому, за словами Клауса Шваба, «платформа є однією з важливих моделей діяльності, яка стала можливою за рахунок мережевих ефектів переходу в цифровий формат. Якщо за часів третьої промислової революції виникали суто цифрові платформи, то відмінною рисою четвертої промислової революції є поява глобальних платформ, тісно пов'язаних з фізичним світом».

Крім того, цифровізація ставить серйозні питання і для майбутніх компетенцій, які мають бути сформовані у фахівців, що обслуговують бізнес-процеси та працюють 3 клієнтами. Тому цифровізація має не тільки економічний вплив, але й соціальний та суспільний, адже трансформує попит на робочу силу. Так безперервні технологічні розробки та інновації трансформують компетенції та навички, необхідні для створюваних робочих місць, визначаючи нові типи трудових ролей, відкидаючи застарілі набори робочих функцій. Отже, в довгостроковій перспективі можна поставити під сумнів надійність існуючої зайнятості, враховуючи зміну характеру ринку праці та наявних робочих місць.

Разом 3 тим, виходячи з соціально-економічних дисбалансів та асиметрій економічного розвитку, додаткового дослідження вимагає диференціація у рівні доступності мережевих технологій та хмарних сервісів населенню та фірмам. Зокрема, постає логічне питання: а чи готова Україна до масової та форсованої цифровізації всіх аспектів суспільного життя - від бізнес-процесів до сфери публічного управління - та які фактори сприяють найбільш вдалій та продуктивній цифровізації економічної взаємодії, адже в Україні про активну розбудову цифрового суспільства йдеться у Проекті Закону України «Про цифровий порядок денний України» від 03.09.2017 р. [27] та Концепції розвитку цифрової економіки та суспільства України на 2018-2020 pp. і плані заходів щодо ії реалізації [25].

3 цією метою використано дані Світового банку та структуровано країни за регіонами (це дозволяє визначити географічну сегментацію онлайн-активності населення), рівнем доходів (вказує на різницю в доступі у країнах, які забезпечують різні рівні національного доходу), а також рівнем економічного розвитку (виходячи $з$ припущення, що зрілість економічної системи знаходиться у тісному зв'язку 3 доступністю мережі Інтернет). Окрему увагу слід звернути на класифікацію країн за демографічними 
дивідендами, адже саме їх стадія визначає вікову структуру населення, доступність освіти та віддачу від зростання продуктивності, яка стимульована, окрім іншого, автоматизацією та цифровізацією бізнеспроцесів.

Не дивлячись на те, що наявність доступу до мережі Інтернет на сьогодні не вважається виключним благом, поширеність такого доступу у світі $є$ досить різною залежно від географічного регіону (табл. 1).

Табличя 1

Частка населення, щзо має доступ до мережі Інтернет,\% (за роками та географічними регіонами світу)

\begin{tabular}{|c|c|c|c|c|}
\hline \multirow[t]{2}{*}{ Групи країн } & \multicolumn{4}{|c|}{$\begin{array}{c}\text { Частка населення, що мас доступ до } \\
\text { мережі Інтернет, \% (за роками)* }\end{array}$} \\
\hline & 1990 & 2000 & 2010 & 2017 \\
\hline Cвiт & 0,05 & 6,74 & 28,73 & 48,57 \\
\hline Свропа та Центральна Азія (Europe \& Central Asia) & 0,05 & 13,16 & 56,09 & 74,91 \\
\hline - за виключенням країн з високим рівнем доходів & 0,00 & 1,97 & 35,58 & 66,38 \\
\hline Свропейський Союз (European Union) & 0,07 & 20,51 & 70,71 & 80,64 \\
\hline $\begin{array}{l}\text { Центральна Свропа та Балтія } \\
\text { (Central Europe and the Baltics)** }\end{array}$ & $\mathbf{0 , 0 0}$ & $\mathbf{7 , 0 5}$ & 58,60 & 73,44 \\
\hline Північна Америка (North America) & 0,74 & 43,89 & 72,55 & 77,01 \\
\hline Східна Азія та Тихоокеанський регіон (East Asia \& Pacific) & 0,01 & 5,62 & 34,27 & 55,10 \\
\hline - за виключенням країн з високим рівнем доходів & 0,00 & 1,89 & 28,96 & 50,79 \\
\hline $\begin{array}{l}\text { Латинська Америка та Карибський регіон } \\
\text { (Latin America \& Caribbean) }\end{array}$ & 0,00 & 3,89 & 34,71 & 62,14 \\
\hline - за виключенням країн з високим рівнем доходів & 0,00 & 3,37 & 34,16 & 61,41 \\
\hline $\begin{array}{c}\text { Близький Схід та Північна Африка } \\
\text { (Middle East \& North Africa) }\end{array}$ & 0,00 & 1,69 & 24,87 & 55,15 \\
\hline - за виключенням країн з високим рівнем доходів & 0,00 & 0,84 & 20,73 & 50,02 \\
\hline Південна Азія (South Asia) & 0,00 & 0,47 & 7,21 & 30,19 \\
\hline Африка на південь від Сахари (Sub-Saharan Africa) & 0,00 & 0,51 & 6,99 & 22,12 \\
\hline - за виключенням країн з високим рівнем доходів & 0,00 & 0,51 & 6,99 & 22,11 \\
\hline
\end{tabular}

Довідка: * дані зведено автором за даними World Bank [12];

** напівжирним шрифтом виділено групу країн, до якої входить Україна

Так у Європі та Центральній Азії 74,9 \% населення має доступ до Інтернету (у 2010 р. цей показник становив 56,1 \%). Це вказує на інтенсивний розвиток та поширення Інтернет-технологій у країнах регіону. Зауважимо, що у країнах регіону з низькими та середніми доходами частка населення, що мала доступ до мережі Інтернет, становила 35,6 \% та 66,4 \% у 2010 р. та 2017 р. відповідно. Якщо окремо виділити країни СС, то у ці роки відповідні показники становили 70,7 \% та 80,6 \%, що вказує на високий рівень поширення доступу до Інтернет серед населення.

У Північній Америці ще у 2000 р. до Інтернету мали доступ 43,9 \%, а в 2010 р. та 2017 р. ці показники перетнули позначку 70 \% та становили 72,6 \% та 77,0 \% відповідно.

Однак існують регіони, де рівень доступу до Інтернет нижче за середньосвітовий показник $(48,6 \%)-$ це Південна Азія (30,2 \%) та Африка на південь від Сахари (22,1%). Досить низькими є також показники Близького Сходу та Північної Африки (55,2 \%), Східної Азії та Тихоокеанського регіону (55,1%), Латинської Америки (62,1\%).

Цікавою, з точки зору аналізу доступності ресурсів мережі Інтернет для населення, є класифікація країн за категорією демографічних дивідендів. По суті дана категорія означає віддачу від певної вікової структури населення, його соціально-економічних характеристик. Зокрема, існує ряд векторів,у яких країна може здобути демографічні дивіденди, - заощадження, пропозиція робочої сили, людський капітал, економічне зростання. Для їх отримання країна проходить демографічну трансформацію - від етапу сільської аграрної економіки зі значним рівнем народжуваності та смертності, низькою продуктивністю праці (переддемографічні дивіденди) до урбанізованого індустріального суспільства 3 низькою народжуваністю та смертністю, проте високою продуктивністю праці (постдемографічні дивіденди).

Можна зробити припущення про те, що рівень доступу населення до мережі Інтернет в цих умовах буде різнитися, а віддача досягнення цілей суспільного та економічного розвитку буде збільшуватися зі зростанням демографічних дивідендів.

У таблиці 2 за даними Світового банку проаналізовано динаміку зростання частки населення, що має доступ до Інтернету залежно від стадії демографічних дивідендів країни. 
Частка населення, щуо має доступ до мережі Інтернет, \% (за роками та за рівнем демографічних дивідендів)

\begin{tabular}{|c|c|c|c|c|}
\hline \multirow[t]{2}{*}{ Групи країн } & \multicolumn{4}{|c|}{$\begin{array}{c}\text { Частка населення, що має доступ } \\
\text { до мережі Інтернет, \% (за роками)* }\end{array}$} \\
\hline & 1990 & 2000 & 2010 & 2017 \\
\hline Світ & 0,05 & 6,74 & 28,73 & 48,57 \\
\hline \multicolumn{5}{|c|}{$\begin{array}{l}\text { Регіони за рівнем демографічних дивідендів } \\
\text { (Region by demographic dividend) }\end{array}$} \\
\hline $\begin{array}{c}\text { Переддемографічні дивіденди } \\
\text { (Pre-demographic dividend) }\end{array}$ & 0,00 & 0,12 & 6,10 & 20,28 \\
\hline $\begin{array}{l}\text { Ранні демографічні дивіденди } \\
\text { (Early-demographic dividend) }\end{array}$ & 0,00 & 1,23 & 12,84 & 37,86 \\
\hline $\begin{array}{l}\text { Пізні демографічні дивіденди } \\
\text { (Late-demographic dividend)** }\end{array}$ & $\mathbf{0 , 0 0}$ & 2,47 & 36,03 & 58,86 \\
\hline $\begin{array}{l}\text { Постдемографічні дивіденди } \\
\text { (Post-demographic dividend) }\end{array}$ & 0,27 & 30,55 & 70,98 & 80,86 \\
\hline
\end{tabular}

Довідка: * дані зведено автором за даними World Bank [12];

** напівжирним шрифтом виділено групу країн, до якої входить Україна

Як бачимо, протягом 1990-х рр. у країнах з переддемографічними дивідендами доступ до мережі Інтернет отримали лише $0,12 \%$, ще $6 \%$ - протягом наступного десятиліття і тільки у 2017 р. ця частка сягнула 20,28\%. Для порівняння варто сказати, що в країнах постдемографічних дивідендів протягом майже трьох десятиліть з 1990 по 2017 рр. ця частка зростала до 30,55 \%, 70,98 \% та досягла позначки $80,86 \%$ у 2017 p.

Як вказують Х.Маргетт (H.Margetts), П.Данліві (P.Dunleavy) [14], «коли аналізувалися демографічні показники користувачів електронних сервісів, різниці між бідними/багатими, етнічними меншинами, низькою/високою освітою не виявлено - лише за віком. Такі дані свідчать про те, що там, де громадяни справді чогось хочуть, вони готові спробувати електронне спілкування. Якщо ж послуги недоступні, ще однією перешкодою для їх розвитку може бути відсутність активного попиту на них з боку громадян». Така різниця продовжує подальший розрив у рівні доступу населення до благ громадянського суспільства, посилює розрив у рівні продуктивності праці і в результаті на глобальному рівні визначає вектори переміщень робочої сили.

3 іншого боку, саме використання засобів глобальної мережі активізується на основі інтенсивних інноваційних перетворень, розвитку інтелектуального капіталу, а також значного фінансування цифрових технологій.

Тому в своєму досліджені Ю.І. Онищенко вирізняє основні причини формування цифрової економіки: «Дослідження причин формування цифрової економіки в розвинених країнах довело, що однією з основних $€$ циклічність економіки та зміна технологічних укладів. Так поштовхом до переходу в наступний технологічний уклад практично завжди є різкий спад темпів приросту ВВП, що спричиняє пошук нових технологій, винаходів, відкриттів, які докорінно змінюють зміст різних видів діяльності в суспільстві» [21, с. 13].

Розрив у доступі населення до мережі Інтернет можна відслідкувати і серед країн з різними рівнями доходів на душу населення та щаблями (або подекуди і умовами) соціально-економічного розвитку (табл. 3).

Як бачимо, розрив у продемонстрованих показниках надзвичайно великий. Проте відслідкувати складні причинно-наслідкові зв'язки між рівнем ВВП та доступом населення до Інтернет однозначно не можна. Адже, чим вища величина доходів на душу населення, тим більші можливості використання комп'ютерних технологій та телекомунікаційних засобів у повсякденному житті. Проте, з іншого боку, зростання доступу до мережі Інтернет сприяє розвитку освіти і науки в країні, що також призводить до зростання продуктивності праці та створення суспільного продукту.

Проте навіть і серед розвинених країн можна спостерігати значні розриви у рівні цифровізації їх економіки та суспільства. Так значні відмінності у використанні хмарних технологій у господарській діяльності спостерігаються в країнах-членах ЄС. За даними Eurostat, «більше половини підприємств використовували хмарні обчислення у Фінляндії (57 \%), а понад 40 \% - у Швеції (48 \%) та Данії (42\%). Проте послугами хмарних обчислень користувалися менше 10 \% підприємств у Болгарії та Румунії (по 7 \%), Латвії та Польщі (по 8 \%), а також Греції (9 \%)» [5]. 
Частка населення, щзо має доступ до мережі Інтернет, \% (за роками та рівнем економічного розвитку/рівнем доходу)

\begin{tabular}{|c|c|c|c|c|}
\hline \multirow{2}{*}{ Групи країн } & \multicolumn{4}{|c|}{$\begin{array}{c}\text { Частка населення, що мас доступ } \\
\text { до мережі Інтернет, \% (за роками)* }\end{array}$} \\
\hline & 1990 & 2000 & 2010 & 2017 \\
\hline Світ & 0,05 & 6,74 & 28,73 & 48,57 \\
\hline \multicolumn{5}{|l|}{$\begin{array}{l}\text { Регіони за рівнем економічного розвитку } \\
\text { (Region by economic development) }\end{array}$} \\
\hline $\begin{array}{l}\text { Недієздатні та уражені конфліктом країни } \\
\text { (Fragile and conflict affected situations) }\end{array}$ & 0,00 & 0,26 & 6,05 & 22,46 \\
\hline $\begin{array}{l}\text { Найменш розвинені країни за класифікацією ООН } \\
\text { (Least developed countries: UN classification) }\end{array}$ & 0,00 & 0,10 & 4,13 & 17,78 \\
\hline Країни-члени OECP (OECD members) & 0,24 & 27,83 & 67,63 & 79,26 \\
\hline \multicolumn{5}{|l|}{ Регіони за рівнем доходу (Region by income) } \\
\hline Країни з низьким рівнем доходу (Low income) & 0,00 & 0,10 & 4,20 & 15,41 \\
\hline $\begin{array}{c}\text { Країни } 3 \text { рівнем доходу нижче середнього } \\
\text { (Lower middle income) }\end{array}$ & $\mathbf{0 , 0 0}$ & $\mathbf{0 , 5 6}$ & 10,72 & 33,58 \\
\hline Країни з середнім рівнем доходу (Middle income) & 0,00 & 1,57 & 21,76 & 45,33 \\
\hline $\begin{array}{c}\text { Країни з рівнем доходу вище середнього } \\
\text { (Upper middle income) }\end{array}$ & 0,00 & 2,48 & 33,48 & 58,43 \\
\hline Країни з високим рівнем доходу (High income) & 0,26 & 30,46 & 72,13 & 82,43 \\
\hline
\end{tabular}

Довідка: * дані зведено автором за даними World Bank [12];

** напівжирним шрифтом виділено групу країн, до якої входить Україна

Для більш широкого погляду на стан розвитку елементів цифровізації суспільства під час дослідження нами проаналізовано дані Індексу цифрової економіки та суспільства (Digital Economy and Society Index) [6] за 2018 p. 3 цією метою розраховано показники варіації за окремими його компонентами. Сукупність показників включала бальні оцінки відповідних компонентів для кожної країни ЄС. Їх візуалізація представлена на рисунку 1.

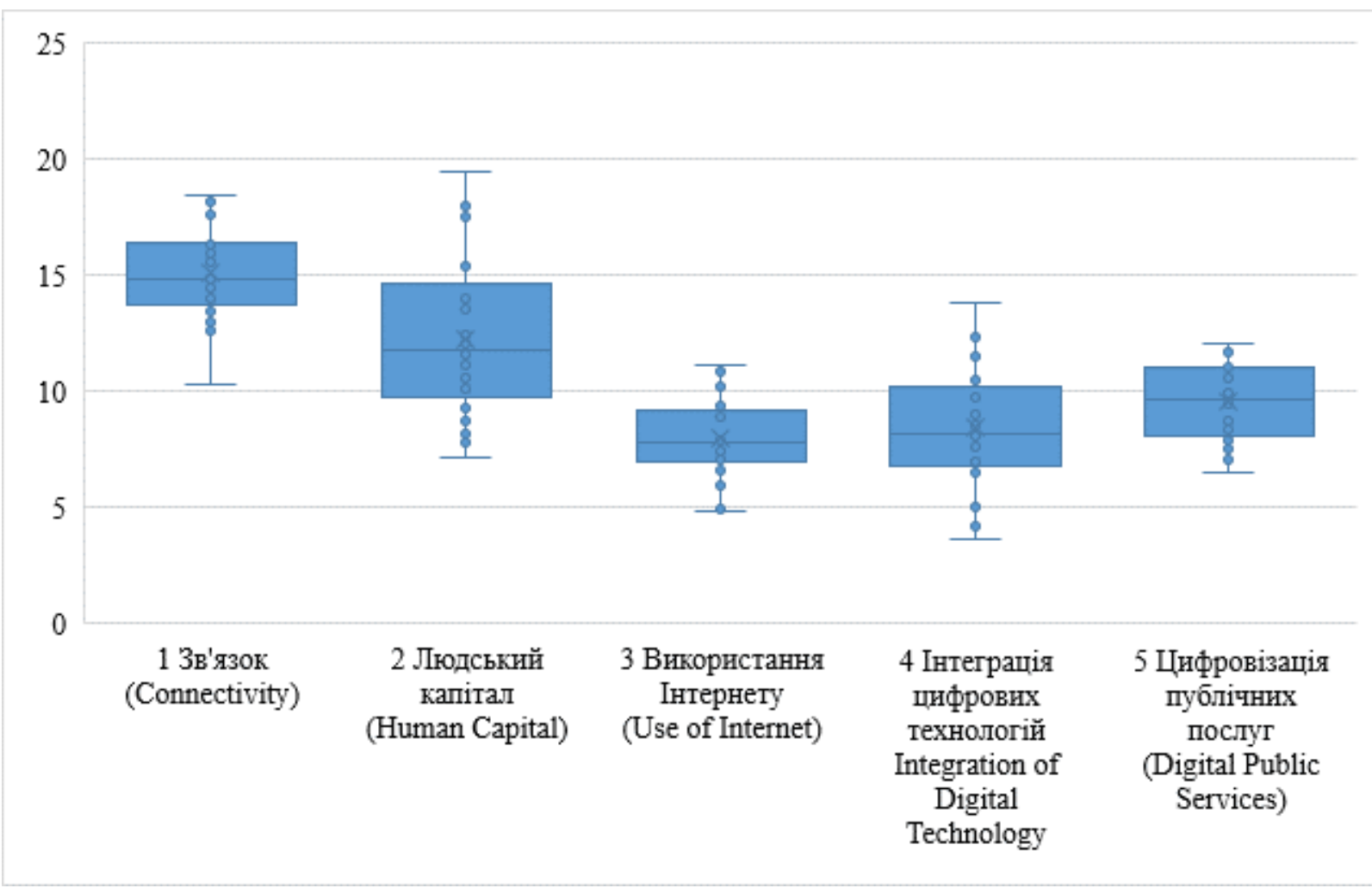

Довідка: розраховано та побудовано за даними Digital Economy and Society Index [6]

Рис. 1. Варіація бальної оцінки краӥн СС за окремими компонентами Індексу ичифрової економіки та суспільства 
I якщо за рівнем цифровізації публічних (громадських) послуг розрив між досліджуваними країнами мінімальний, то компонент «Людський капітал» демонструє значну диференціацію у країнах ЄС. Можемо пояснити це різним рівнем освіти населення, фінансування державами сфери освіти і науки.

У питаннях побудови цифрового суспільства й активізації використання засобів цифровізації бізнесом та населенням не стала виключенням і Україна. Зокрема, у ще в 2015 р. було прийнято ряд документів, які були першим кроком на шляху до цифровізації окремих адміністративних та економічних процесів: Закон України «Про електронну комерцію» від 03.09.2015 № 675-VIII [24] та Постанова Кабінету міністрів України від 21 жовтня 2015 р. № 835 «Про затвердження Положення про набори даних, які підлягають оприлюдненню у формі відкритих даних» [22].

Зокрема, першим документом закладено підвалини для правового регулювання правових відносин у сфері електронної комерції під час вчинення електронних правочинів.

Також прикладний характер мають положення другого документа, оскільки саме він формулює вимоги до формату та структури наборів даних, які підлягають оприлюдненню як відкриті дані, їх перелік та, крім того, встановлюють періодичність оновлення та власне порядок такого оприлюднення.

При цьому не менш важливим було прийняття Закону України «Про електронні довірчі послуги» від 05.10.2017 № 2155-VIII [23], який створив нормативно-правовий базис реалізації проектів, пов'язаних 3 цифровізацією правочинів у всіх сферах суспільного життя, ідентифікації користувачів системи електронних послуг.

Разом 3 тим, зауважимо, що концептуалізація засад побудови цифрової економіки відбулася пізніше - із прийняттям Проекту Закону України «Про цифровий порядок денний України» від 03.09.2017 [27]. Даний проєкт визначає сфери застосування цифровізації, конкретизуючи зокрема іiі відмінності від інформатизації. Однак, досить декларативними $\epsilon$ положення Концепції розвитку цифрової економіки та суспільства України на 2018-2020 pp. та план заходів щодо ії реалізації [25], що конкретизована у Проєкті Цифрової адженди України [26].

Вивчення національної системи регулювання сфери електронних послуг, що урегульовує питання цифровізації суспільно-економічних та інших відносин, зокрема i функціонування системи бухгалтерського обліку, встановило, що частково такі правовідносини регулюються також іншими документами, ухваленими у різний час. Наголосимо, що ці документи містять ряд неугодженостей, оскільки не базувалися на єдиних концептуальних засадах цифровізації:

- Закон України «Про електронні документи та електронний документообіг» № 851-IV від 07.11.2018 [17];

- Закон України «Про електронні довірчі послуги» № 2155-VIII від 05.10.2017 [16];

- Закон України «Про платіжні системи та переказ коштів в Україні» № 2346-III від 07.02.2019 [19];

- Закон України «Про фінансові послуги та державне регулювання ринків фінансових послуг» № 2664-ІІІ від 07.02.2019 [20];

- Закон України «Про захист персональних даних» № 2297-VI від 30.01.2018 [18].

Крім того, в даній сфері застосовується ряд міжнародних договорів України, обов'язкове виконання яких було дозволене Верховною Радою України.

Вказані нормативно-правові документи складають основу легітимізації операцій за допомогою електронного цифрового підпису, що, у свою чергу, дозволяє їх в подальшому використовувати як доказову базу при відображенні операцій в обліку. При цьому саме відображення в цифровому середовищі є автоматичними та здійснюється на основі результатів верифікації документів.

Висновки та перспективи подальших досліджень. Таким чином, на основі проведеного дослідження, сформульовано такі висновки:

1. Глобальні суспільні перетворення, якими обумовлюється зростання динамічності економічного середовища, визначають шляхи та моделі розвитку сучасного бізнесу, створюють небачені можливості підвищення його конкурентоспроможності на основі віртуалізації. Вона $є$ певним логічними кроком у поступі процесів глобалізації суспільства, адже виробництво товарів та послуг у світі вже давно вийшло за національні кордони, транснаціоналізувавши ланцюги доданої вартості та зробивши їх глобальними. В кінцевому підсумку ми дійшли до розуміння концепції Індустрії 4.0, яка у сфері економічних взаємовідносин виявляється у зміні парадигми створення благ, використання ресурсів, в тому числі людських. Проте найбільшої трансформації зазнали дані, створення та володіння якими стало визначальною конкурентною перевагою у віртуальному бізнес-середовищі.

2. Готовність країни до долучення до процесів цифровізації економічного середовища та системи взаємодії між економічними агентами визначається не тільки аспектами спроможності фінансування відповідних проектів, проте й готовністю людських ресурсів (адаптивність їх навичок до освоєнння нових цифрових технологій), соціально-економічним становищем населення (зокрема доступністю засобів мережі Інтернет), матеріально-технічною базою компаній. Проте важливою є також інституційна готовність держави в цілому до підтримки проектів цифровізації, удосконалення системи кібербезпеки, легітимізація цифрових сервісів, використовуваних для взаємодії у системі «держава-компанія-індивід». 
3. Цифровізація суспільства виявляється у зміні парадигми взаємодії економічних агентів та вбирає у себе всі існуючі комунікаційні відносини між суб’єктами трансакцій та стейкхолдерами, створюючи нове віртуальне середовище та пропонуючи нові форми інформаційних взаємин між ними. Саме у таких обставинах організаційно-методологічні засади системи бухгалтерського обліку як інформаційної системи компанії трансформуються, оскільки постає нова концепція формування та використання даних, яка дозволяє цифровізувати та параметризувати ряд об'єктів, які класично не були об'єктами бухгалтерського обліку.

4. Крім того, сам бухгалтерський облік набуває нових функцій - посилюється прогностична функція, оскільки нові бази даних щодо бізнес-процесів компанії сприяють утворенню функцій прогнозування явищ та процесів, виявляючи ї закономірності, що можуть бути використані всіма підсистемами управління компанії.

\section{Список використаної літератури:}

1. Axelsson K. Citizens' Attitudes towards Electronic Identification in a Public E-Service Context-An Essential Perspective in the eID Development Process / K.Axelsson, U.Melin // International Conference on Electronic Government. - Berlin ; Heidelberg : Springer, 2012. - P. 260-272.

2. Belanche D. et al. Trust transfer in the continued usage of public e-services / D.Belanche // Information \& Management. - 2014. - Vol. 51, № 6. - P. 627-640.

3. Buyya R. Intercloud: Utility-oriented federation of cloud computing environments for scaling of application services / R.Buyya, R.Ranjan, R.N. Calheiros // International Conference on Algorithms and Architectures for Parallel Processing. - Berlin ; Heidelberg : Springer, 2010. - P. 13-31.

4. Casalino N. Organizing and Promoting Value Services in Public Sector by a New E-government Approach / N.Casalino, M.Draoli, M.Martino // Proceedings of XIV Workshop dei Docenti e Ricercatori di Organizzazione Aziendale (WOA 2013) / Università La Sapienza. - Rome, 2013.

5. Cloud computing use in EU enterprises [Електронний ресурс]. - Режим доступу : https://ec.europa.eu/eurostat/en/web/products-eurostat-news/-/DDN-20170330-1.

6. Digital Economy and Society Index [Електронний ресурс]. - Режим доступу : https://digital-agendadata.eu/datasets/desi/visualizations.

7. Featherman M.S. Predicting e-services adoption: a perceived risk facets perspective / M.S. Featherman, P.A. Pavlou // International journal of human-computer studies. - 2003. - Vol. 59, № 4. - P. 451-474.

8. Goldkuhl G. Characteristics of Public E-services: Investigating the E-diamond Model / G.Goldkuhl, A.Persson // PragWeb. - 2006. - P. 166-181.

9. Gustafsson M. Safe Online e-Services Building Legitimacy for E-government. A Case Study of Public E-services in Education in Sweden / M.Gustafsson, W.Elin // IJeDEM-eJournal of eDemocracy and Open Government. 2014. - Vol. 5, № 2. - P. 155-173.

10. Heidemann J. How To Increase Public E-Services Usage In Governments-A Case Study Of The German Federal Employment Agency / J.Heidemann, S.Muschter, C.Rauch // IECIS. - 2013. - P. 128.

11. Ilshammar L. Public E-Services in Sweden: Old Wine in New Bottles? / L.Ilshammar, A.Bjurström, A.Grönlund // Scandinavian Journal of Information Systems. - 2005. - Vol. 17, № 2. - P. 3.

12. Individuals using the Internet (\% of population) / World Bank [Електронний ресурс]. - Режим доступу : https://data.worldbank.org/indicator/IT.NET.USER.ZS.

13. Lindgren I. Electronic services in the public sector: a conceptual framework / I.Lindgren, G.Jansson // Government Information Quarterly. - 2013. - Vol. 30, № 2. - P. 163-172.

14. Margetts $H$. Better Public Services through e-government: Academic Article in support of Better Public Services through e-government / H.Margetts, P.Dunleavy. - 2002.

15. Використання інформаційно-комунікаційних технологій на підприємствах у 2018 році / Державна служба статистики України. - 2018 [Електронний ресурс]. - Режим доступу : http://www.ukrstat.gov.ua/operativ/operativ2018/zv/ikt/viktp2018_u.xls.

16. Про електронні довірчі послуги : Закон України № 2155-VIII від 05.10.2017 / Верховна Рада України [Електронний ресурс]. - Режим доступу : https://zakon.rada.gov.ua/laws/show/2155-19.

17. Про електронні документи та електронний документообіг : Закон України № 851-IV від 07.11.2018 / Верховна Рада України [Електронний ресурс]. - Режим доступу : https://zakon.rada.gov.ua/laws/show/851-15.

18. Про захист персональних даних : Закон України № 2297-VI від 30.01.2018 / Верховна Рада України [Електронний ресурс]. - Режим доступу : https://zakon.rada.gov.ua/laws/show/2297-17.

19. Про платіжні системи та переказ коштів в Україні : Закон України № 2346-III від 07.02.2019 / Верховна Рада України [Електронний ресурс]. - Режим доступу : https://zakon.rada.gov.ua/laws/show/2346-14.

20. Про фінансові послуги та державне регулювання ринків фінансових послуг : Закон України № 2664-III від 07.02.2019 / Верховна Рада України [Електронний ресурс]. - Режим доступу : https://zakon.rada.gov.ua/laws/show/2664-14.

21. Онищенко Ю.І. Еволюція теоретичних підходів до визначення сутності дефініції «цифрова економіка» / Ю.І. Онищенко // Бізнес-навігатор. - 2018. - Вип. 6. - С. 9-13 [Електронний ресурс]. - Режим доступу : http://nbuv.gov.ua/UJRN/bnav_2018_6_3.

22. Положення про набори даних, які підлягають оприлюдненню у формі відкритих даних : Постанова Кабінету Міністрів України № 835 від 21 жовтня 2015 р. / Верховна Рада України [Електронний ресурс]. Режим доступу : http://zakon2.rada.gov.ua/laws/show/835-2015-\%D0\%BF. 
23. Про електронні довірчі послуги : Закон України № 2155-VIII від 05.10.2017 / Верховна Рада України [Електронний ресурс]. - Режим доступу : http://zakon2.rada.gov.ua/laws/show/2155-19.

24. Про електронну комерцію : Закон України № 675-VIII від 03.09.2015 / Верховна Рада України [Електронний ресурс]. - Режим доступу : http://zakon5.rada.gov.ua/laws/show/675-19.

25. Про схвалення Концепції розвитку цифрової економіки та суспільства України на 2018-2020 роки та затвердження плану заходів щодо іiі реалізації : Розпорядження Кабінету Міністрів України № 67-р. від 17.01.2018 p. / Верховна Рада України [Електронний ресурс]. - Режим доступу : http://zakon2.rada.gov.ua/laws/show/67-2018-\%D1\%80.

26. Проект Цифрової адженди України / Офіційний сайт Торгово-промислової палати України ; Торговопромислова палата України [Електронний ресурс]. - Режим доступу https://ucci.org.ua/uploads/files/58e78ee3c3922.pdf.

27. Про цифровий порядок денний України : Проект Закону України від 03.09.2017 / Верховна Рада України [Електронний ресурс]. - Режим доступу : http:// iportal.rada.gov.ua/uploads/documents/40009.pdf.

\section{References:}

1. Axelsson, K. and Melin, U. (2012), «Citizens' Attitudes towards Electronic Identification in a Public E-Service Context-An Essential Perspective in the eID Development Process», International Conference on Electronic Government, Springer, Berlin, Heidelberg, pp. 260-272.

2. Belanche, D. and others (2014), «Trust transfer in the continued usage of public e-services», Information \& Management, Vol. 51, No. 6, pp. 627-640.

3. Buyya, R., Ranjan, R. and Calheiros, R.N. (2010), «Intercloud: Utility-oriented federation of cloud computing environments for scaling of application services», International Conference on Algorithms and Architectures for Parallel Processing, Springer, Berlin, Heidelberg, pp. 13-31.

4. Casalino, N., Draoli, M. and Martino, M. (2013), «Organizing and Promoting Value Services in Public Sector by a New E-government Approach», Proceedings of XIV Workshop dei Docenti e Ricercatori di Organizzazione Aziendale (WOA 2013), Università La Sapienza, Rome.

5. «Cloud computing use in EU enterprises» (2017), [Online], available at: https://ec.europa.eu/eurostat/en/web/products-eurostat-news/-/DDN-20170330-1

6. «Digital Economy and Society Index», [Online], available at: https://digital-agendadata.eu/datasets/desi/visualizations

7. Featherman, M.S. and Pavlou, P.A. (2003), «Predicting e-services adoption: a perceived risk facets perspective», International journal of human-computer studies, Vol. 59, No. 4, pp. 451-474.

8. Goldkuhl, G. and Persson, A. (2006), «Characteristics of Public E-services: Investigating the E-diamond Model», PragWeb, pp. 166-181.

9. Gustafsson, M. and Elin, W. (2014), «Safe Online e-Services Building Legitimacy for E-government. A Case Study of Public E-services in Education in Sweden», IJeDEM-eJournal of eDemocracy and Open Government, Vol. 5, No. 2, pp. 155-173.

10. Heidemann, J., Muschter, S. and Rauch, C. (2013), «How To Increase Public E-Services Usage In Governments-A Case Study Of The German Federal Employment Agency», IECIS, P. 128.

11. Ilshammar, L., Bjurström, A. and Grönlund, Å. (2005), «Public E-Services in Sweden: Old Wine in New Bottles?», Scandinavian Journal of Information Systems, Vol. 17, No. 2, P. 3.

12. World Bank, «Individuals using the Internet (\% of population)», [Online], available at: https://data.worldbank.org/indicator/IT.NET.USER.ZS

13. Lindgren, I. and Jansson, G. (2013), «Electronic services in the public sector: a conceptual framework», Government Information Quarterly, Vol. 30, No. 2, pp. 163-172.

14. Margetts, H. and Dunleavy, P. (2002), Better Public Services through e-government: Academic Article in support of Better Public Services through e-government.

15. Derzhavna sluzhba statystyky Ukrai'ny (2018), «Vykorystannja informacijno-komunikacijnyh tehnologij na $\begin{array}{lllll}\text { pidpryjemstvah } \mathrm{u} & 2018 \text { roci», }\end{array}$ http://www.ukrstat.gov.ua/operativ/operativ2018/zv/ikt/viktp2018_u.xls

16. Verhovna Rada Ukrai'ny (2017), «Pro elektronni dovirchi poslugy», zakon, No. 2155-VIII, vid 05 zhovtnja, [Online], available at: https://zakon.rada.gov.ua/laws/show/2155-19

17. Verhovna Rada Ukrai'ny (2018), «Pro elektronni dokumenty ta elektronnyj dokumentoobig», zakon, No. 851-IV, vid 07 lystopada, [Online], available at: https://zakon.rada.gov.ua/laws/show/851-15

18. Verhovna Rada Ukrai'ny (2018), «Pro zahyst personal'nyh danyh», zakon, No. 2297-VI, vid 30 sichnja, [Online], available at: https://zakon.rada.gov.ua/laws/show/2297-17

19. Verhovna Rada Ukrai'ny (2019), «Pro platizhni systemy ta perekaz koshtiv v Ukrai'ni», zakon, No. 2346-III, vid 07 ljutogo, [Online], available at: https://zakon.rada.gov.ua/laws/show/2346-14

20. Verhovna Rada Ukrai'ny (2019), «Pro finansovi poslugy ta derzhavne reguljuvannja rynkiv finansovyh poslug», zakon, No. 2664-III, vid 07 ljutogo, [Online], available at: https://zakon.rada.gov.ua/laws/show/2664-14

21. Onyshhenko, Ju.I. (2018), «Evoljucija teoretychnyh pidhodiv do vyznachennja sutnosti definicii' «cyfrova ekonomika»"), Biznes-navigator, Vol. 6, pp. 9-13, [Online], available at: http://nbuv.gov.ua/UJRN/bnav_2018_6_3

22. Verhovna Rada Ukrai'ny (2015), «Polozhennja pro nabory danyh, jaki pidljagajut' opryljudnennju u formi vidkrytyh danyh», Postanova, Kabinet Ministriv Ukrai'ny, No. 835, vid 21 zhovtnja, [Online], available at: http://zakon2.rada.gov.ua/laws/show/835-2015-\%D0\%BF 
23. Verhovna Rada Ukrai'ny (2017), «Pro elektronni dovirchi poslugy», zakon, No. 2155-VIII, vid 05 zhovtnja, [Online], available at: http://zakon2.rada.gov.ua/laws/show/2155-19

24. Verhovna Rada Ukrai'ny (2015), «Pro elektronnu komerciju», zakon, No. 675-VIII, vid 03 veresnja, [Online], available at: http://zakon5.rada.gov.ua/laws/show/675-19

25. Verhovna Rada Ukrai'ny (2018), «Pro shvalennja Koncepcii' rozvytku cyfrovoi' ekonomiky ta suspil'stva Ukrai'ny na 2018-2020 roky ta zatverdzhennja planu zahodiv shhodo i'i' realizacii'», Rozporjadzhennja, Kabinet Ministriv Ukrai'ny, No. 67-r., vid 17 sichnja, [Online], available at: http://zakon2.rada.gov.ua/laws/show/67-2018-\%D1\%80

26. Torgovo-promyslova palata Ukrai'ny, «Proekt Cyfrovoi' adzhendy Ukrai'ny», Oficijnyj sajt, [Online], available at: https://ucci.org.ua/uploads/files/58e78ee3c3922.pdf

27. Verhovna Rada Ukrai'ny (2017), «Pro cyfrovyj porjadok dennyj Ukrai'ny», Proekt Zakonu, vid 03 veresnja, [Online], available at: http:// iportal.rada.gov.ua/uploads/documents/40009.pdf

Соколенко Людмила Федорівна - кандидат економічних наук, доцент, доцент кафедри бізнесекономіки та адміністрування Сумського державного педагогічного університету імені А.С. Макаренка.

Наукові інтереси:

- теорія та методологія бухгалтерського обліку у керуючих компаніях сфери житловокомунального господарства.

Стаття надійшла до редакції 27.09.2019. 